\title{
Haliscosamine: a new antifungal sphingosine derivative from the Moroccan marine sponge Haliclona viscosa
}

\author{
Belkassem El-Amraoui ${ }^{1 *}$, Jean-Fançois Biard ${ }^{2}$ and Aziz Fassouane ${ }^{1,3}$
}

\begin{abstract}
In the aim of searching for new antifungal products from marine origin, we have isolated a sphingosine derivative, (9Z)-2-amino-docos-9-ene-1,3,13,14-tetraol (Haliscosamine) from the Moroccan sea sponge Haliclona viscosa using bio-guided (antifungal) HPLC methods. The molecular structure of this compound was elucidated by spectrometric techniques IR, UV, MS and NMR. The isolated metabolite showed a significant antifungal activity against Cryptococcus and Candida species and a weak general toxicity in the brine shrimp lethality test. Further research is needed to study its in vivo activity, as well as to elucidate the mechanism underlying its activity in the hope of a future use in medical mycology.
\end{abstract}

Keywords: Haliscosamine; Haliclona; Candida; Cryptococcus

\section{Introduction}

Our laboratory aims to find new antifungal metabolites from marine origin for use in human medicine on one hand, and on the other hand in phytopathology. Marine invertebrates of Moroccan Atlantic coast are our preferred source of producers of active substances, specifically sponges, known generally to contain secondary metabolites with interesting biological activities (Faulkner 2002) including antimicrobial (Baker et al. 2009), antifungal (Clark et al. 2001), antileishmanial (Dube et al. 2007), antioxidant (Regoli et al. 2004) and cytotoxic activities (Ayyad et al. 2009, Fusetani et al. 1989, Erickson et al. 1997, Rashid et al. 2000). In the first work (El-Amraoui et al. 2010), we screened antifungal activity in hydroalcoholic and organic extracts of 14 sponges and showed that three species of them are active against pathogenic fungi and bacteria: Haplosclerida adocia, Cinachyrella tarentina and Haliclona viscosa. This latter species being shown the most active, we chose it to isolate the active compound. Kupchan partitioning, then multistep HPLC from the organic extract provided a pure active product. We determined its structure and evaluated its antifungal potential and its toxicity.

\footnotetext{
* Correspondence: elamraouibelkassem@yahoo.fr

${ }^{1}$ Faculty of Science, University of Chouaib Doukkali, El-Jadida, Morocco Full list of author information is available at the end of the article
}

\section{Results}

Isolation of the active product

Lyophilized sponge $(800 \mathrm{~g})$ was extracted with $\mathrm{EtOH}$, the extract partitioned between $\mathrm{CH}_{2} \mathrm{Cl}_{2}$ and $\mathrm{H}_{2} \mathrm{O}$, and the organic solution submitted to a Kupchan liquid partition procedure. EtOAc and $\mathrm{MeOH}: \mathrm{H}_{2} \mathrm{O}$ fractions were pooled, then the mixture was successively separated by three steps of HPLC to yield $47 \mathrm{mg}$ of an amorphous pale yellow product. All steps of this isolation were bio-guided by antifungal (agar disc-diffusion) test. The total mass of the product (taking into account other fractions containing isolated compound) was estimated to be $80 \mathrm{mg}$ from $800 \mathrm{~g}$ of dry sponge $(0.01 \%)$.

\section{Molecular structure of the product isolated from Haliclona viscosa}

The molecular formula of the compound was determined to be $\mathrm{C}_{22} \mathrm{H}_{45} \mathrm{NO}_{4}$, indicating one degree of unsaturation, by HRESIMS with the molecular ion peaks at $\mathrm{m} / \mathrm{z} 410.3255$ $\left([\mathrm{M}+\mathrm{Na}]^{+}\right.$) for $\mathrm{C}_{22} \mathrm{H}_{45} \mathrm{NO}_{4} \mathrm{Na}$ (calculated 410.32463, $\delta 2 \mathrm{ppm})$, and $m / z 388.3431\left([\mathrm{M}+\mathrm{H}]^{+}\right)$for $\mathrm{C}_{22} \mathrm{H}_{46} \mathrm{NO}_{4}$ (calculated 388.34268, $\delta 1 \mathrm{ppm}$ ) in positive ion mode. MS analysis of the product $\left([\mathrm{M}+\mathrm{H}]^{+}\right.$, 388) showed fragments at 370, 352, 334, 316 for the loss of four $-\mathrm{OH}$, and 299 for the $-\mathrm{NH}_{2}$. Same analysis was done with the acetylated product showing a $[\mathrm{M}+\mathrm{Na}]^{+}$ion at $m / z 620$ 
consistent with a penta-acetylated product, and fragments at 560, 500, 440 and 380 for the losses of four acetyl moieties (Figure 1). No ion at 320 for a fifth acetyl was observed.

The UV spectrum (in $\mathrm{MeOH}$ ) (Figure 2) showed weak absorptions $(\delta=1178$ at $207.5 \mathrm{~nm}$ and $\delta=228$ at $281.0 \mathrm{~nm})$.

The IR spectrum (Figure 3) showed absorptions at 3358, 1065 and 1048 (hydroxyl), 2926 and 2855 (aliphatic), 1659 and $1630 \mathrm{~cm}^{-1}$ (double bond). No peak was visible for a carbonyl function.

Analysis of ${ }^{1} \mathrm{H}$ (Figure 4), ${ }^{13} \mathrm{C}$ (Figure 5) and HSQC (in deuterated methanol $\mathrm{CD}_{3} \mathrm{OD}$ ) (Figure 6) experiments revealed the presence of 22 carbons with 39 protons, including one methyl, 15 methylens and six methines. Table 1 shows NMR spectroscopic data of compound. The presence of four oxygenated $\mathrm{C}$ atoms at $59.11(\mathrm{C}-1)$, 67.72 (C-3), 73.36 (C-13), 73.81 (C-14), a probably nitrogenated $\mathrm{C}$ atom at $57.72(\mathrm{C}-2)$, and two double bonded carbons at 129.08 (C-9) and 129.82 (C-10) were elucidated. General appearance of the NMR spectra suggested that it is a derivative of the sphingosine. Therefore, the six remaining protons should correspond to one $-\mathrm{NH}_{2}$ and four $-\mathrm{OH}$. From the careful examination of the 2D NMR experiments spectra (HMQC, HMBC (Figures 7, 8, 9 and 10), COSY (Figures 11 and 12), TOCSY (Figure 13)), three different structural units were identified: $\mathrm{C}-1$ to $\mathrm{C}-5, \mathrm{C}-8$ to $\mathrm{C}-16$ and $\mathrm{C}-20$ to $\mathrm{C}$ 22 (Figure 14). However, respective positions of the carbons $9 / 10,8 / 11$ and 13/14 were not clear because there was a strong overlapping of their signals on the ${ }^{1} \mathrm{H}$ NMR spectrum. Experiments with other solvents were limited by the poor solubility of compound in $\mathrm{AcN}$, $\mathrm{CH}_{2} \mathrm{Cl}_{2}$ and $\mathrm{CHCl}_{3}$. Finally, the assignments of the ${ }^{1} \mathrm{H}$ NMR signals were determined by recording a new set of experiments with increased resolution for the corresponding areas, and by extensive ${ }^{1} \mathrm{H}-\mathrm{NMR}$ decoupling experiments (Figures 15, 16, 17 and 18). Consequently,
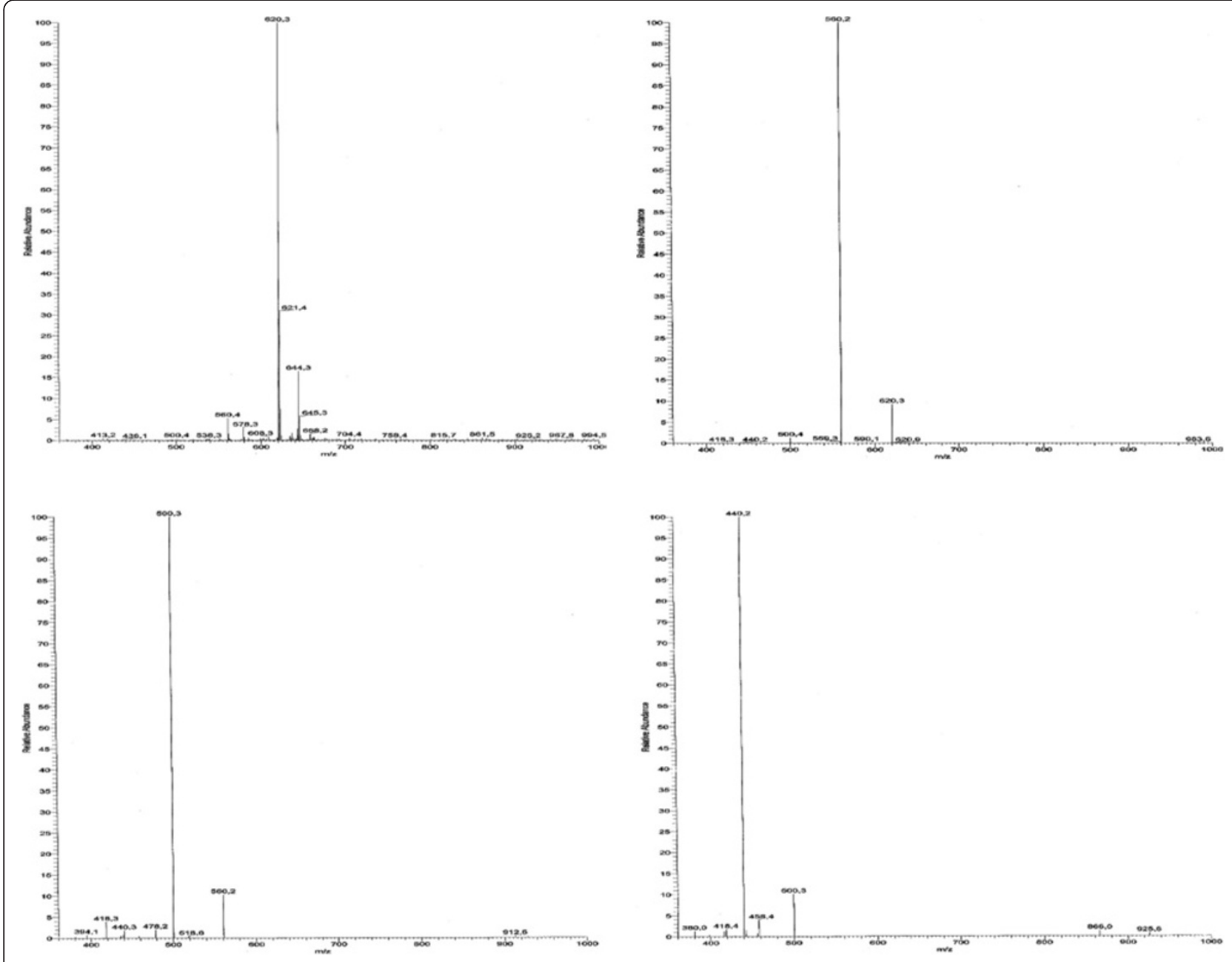

Figure 1 Masse spectrum of acetylated compound. 


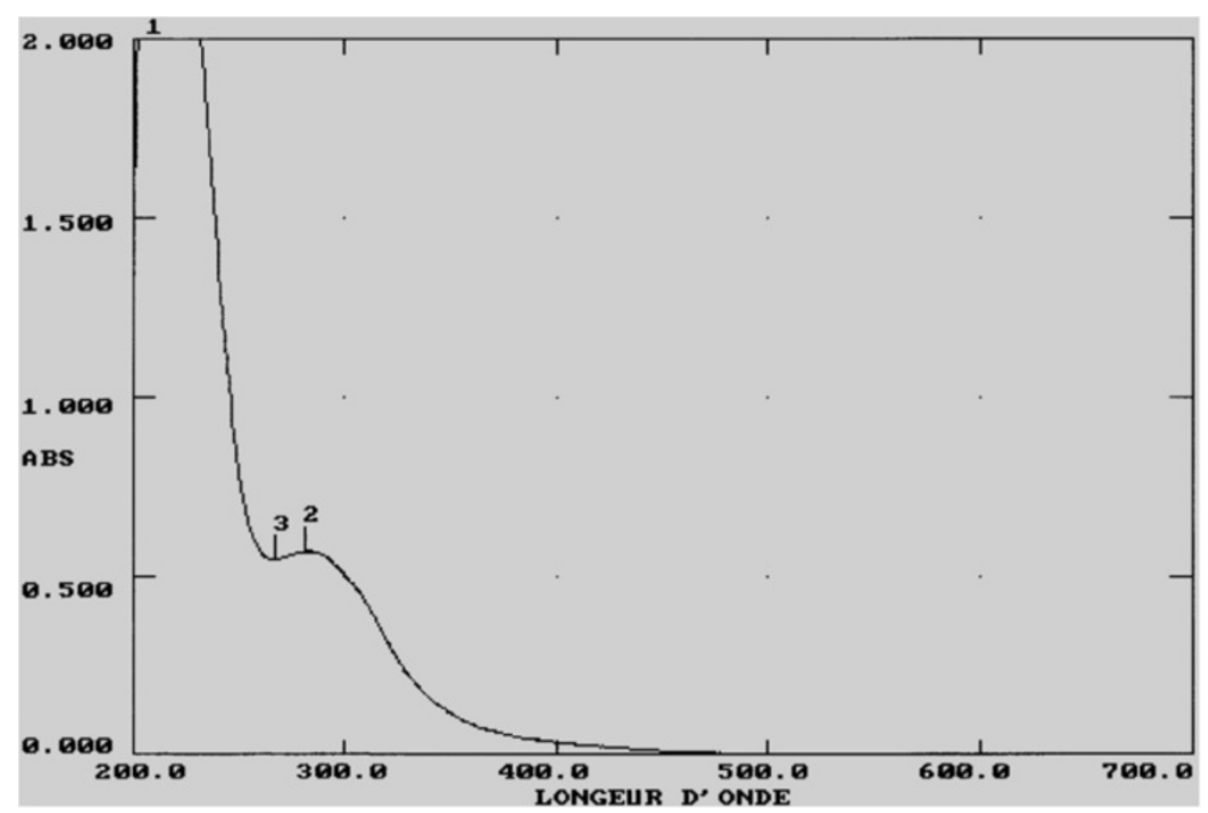

Figure 2 UV-spectrum of haliscosamine.

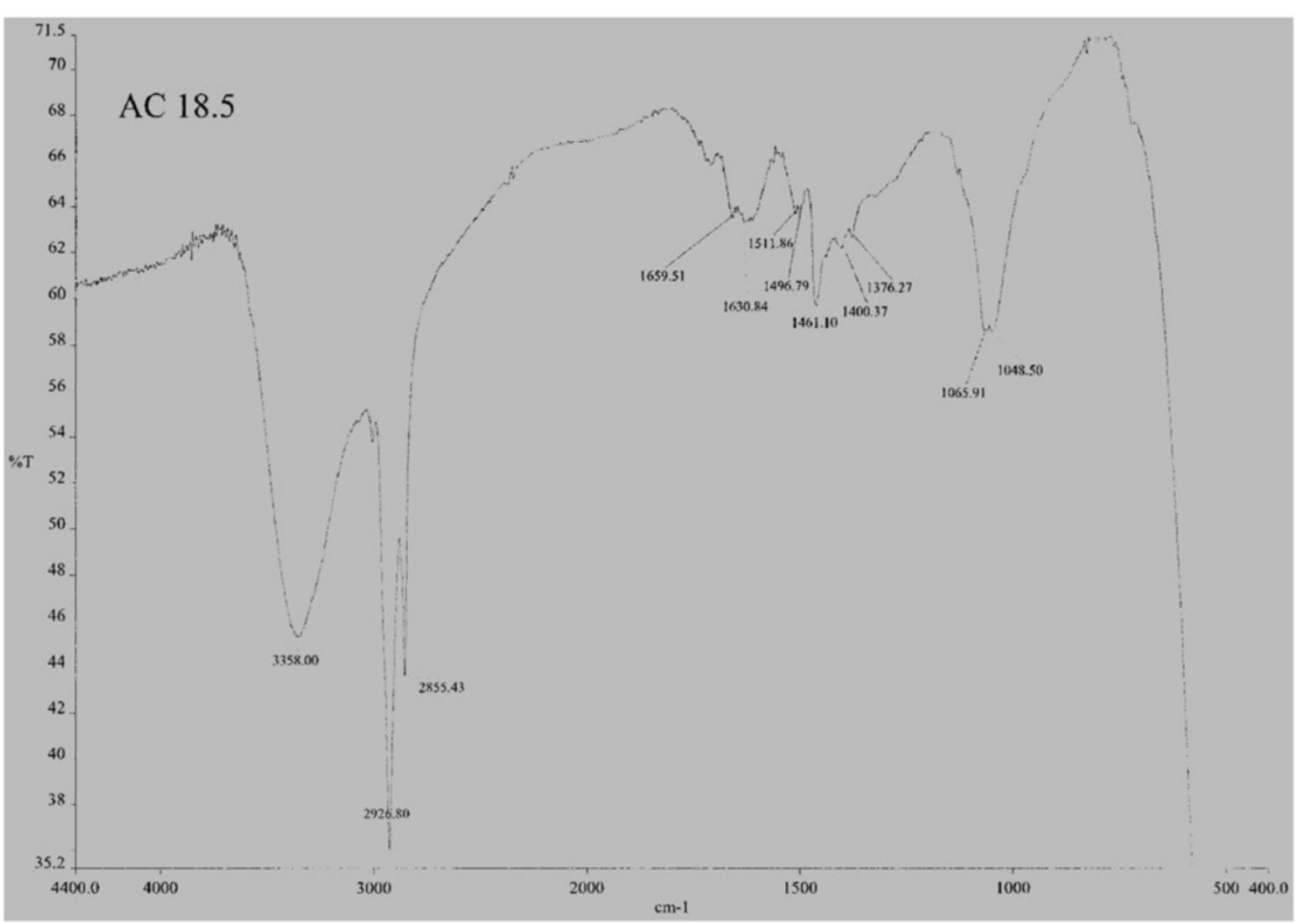

Figure 3 IR spectrum of haliscosamine. 


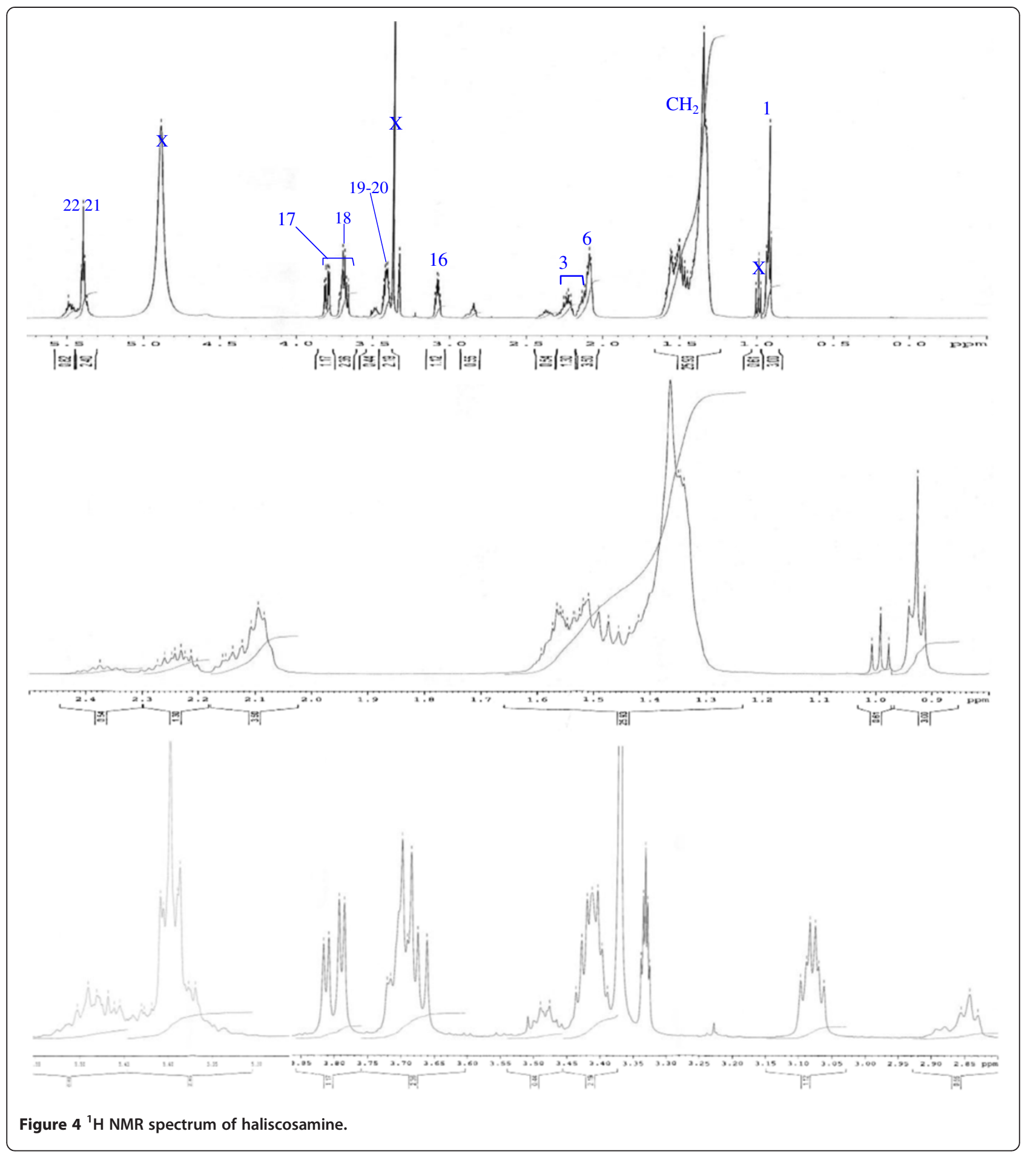

clear relationships between all carbons were established for these three partial structures.

Assemblage of the three sub-structures was done by supplementary ${ }^{1} \mathrm{H}$-NMR decoupling experiments, which allow to link $\mathrm{C}-22$ to $\mathrm{C}-21$ and $\mathrm{C}-20$, then to $\mathrm{C}-16$ by the way of the three $\mathrm{CH}_{2}$ at $29.17,29.18$ and
29.20 (10, 9, 8 respectively). Accordingly, the two last remaining $-\mathrm{CH}_{2}$ (C-6 and C-7) should be positioned between $\mathrm{C}-5$ and $\mathrm{C}-8$ to complete the structural elucidation of compound. Geometry of the double bond was assigned to be $\mathrm{Z}$ on the basis of the ${ }^{1} \mathrm{H}$-NMR experiments: Irradiations at $\delta 2.09$ (Figure 19) (H's of C-8) and 2.28 


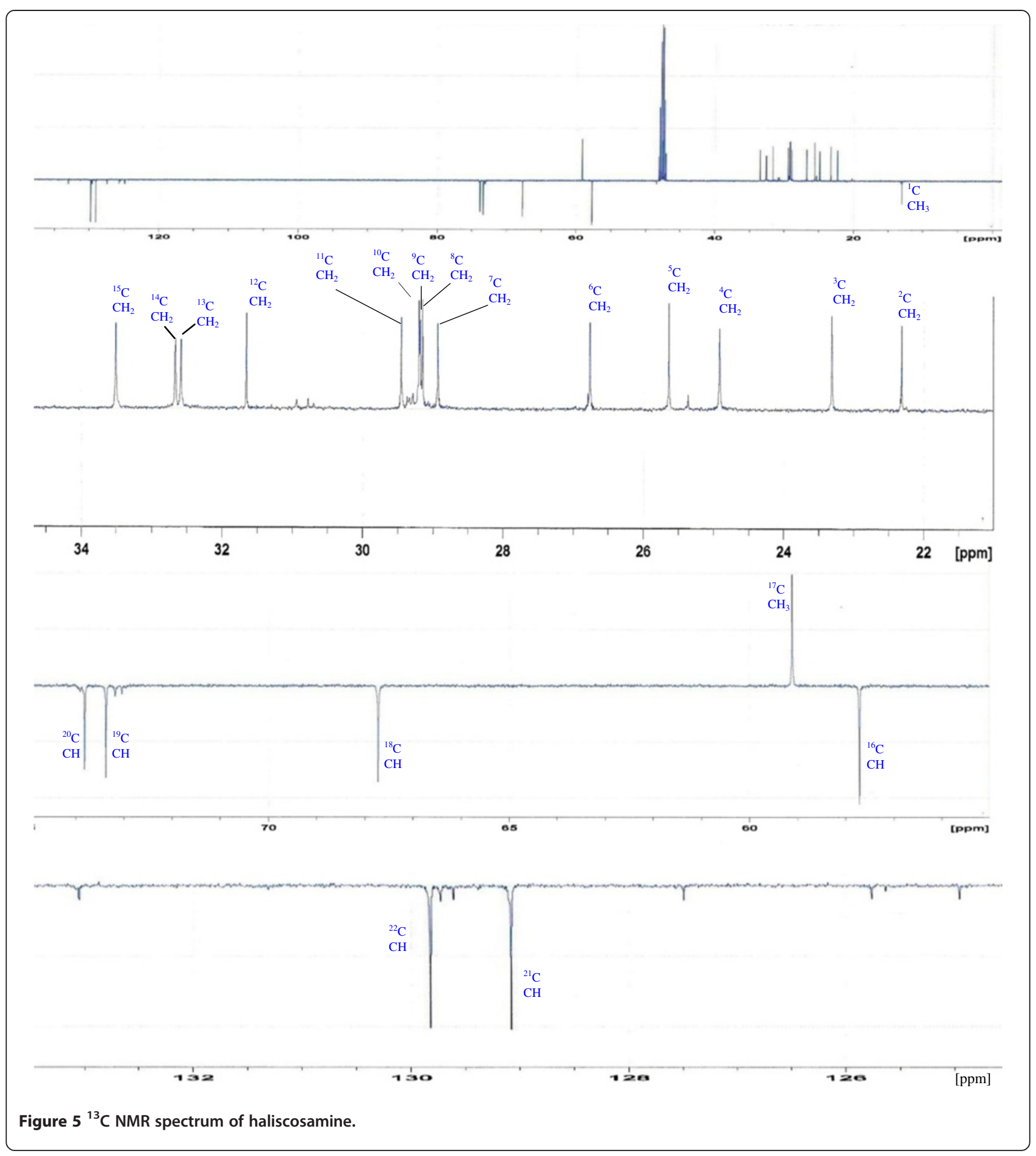

(Figure 20) (H's of C-11) resulted in a change of the olefinic protons group and allowed to found a $10 \mathrm{~Hz}$ coupling constant for these protons. Recording of other ${ }^{1} \mathrm{H}$-NMR spectrum in $\mathrm{CD}_{3} \mathrm{OD}$ with some drops of deuterated benzene $\left(\mathrm{C}_{6} \mathrm{D}_{6}\right)$ (Figure 21) increases the resolution and allowed confirming this $10 \mathrm{~Hz}$ coupling constant. The geometry of the double bond was confirmed by the weak difference between the chemical shifts values of the carbons C-8 (26.77) and C-11 (23.32).

The optical rotation was $[\alpha]_{\mathrm{D}}^{20}=22,3(\mathrm{c}=0,76, \mathrm{MeOH})$. The compound isolated from $H$. viscosa: (9Z)2 -amino-docos-9-ene-1,3,13,14-tetraol (Figure 22), is a new sphingosine derivative. Therefore, we named this product haliscosamine. 


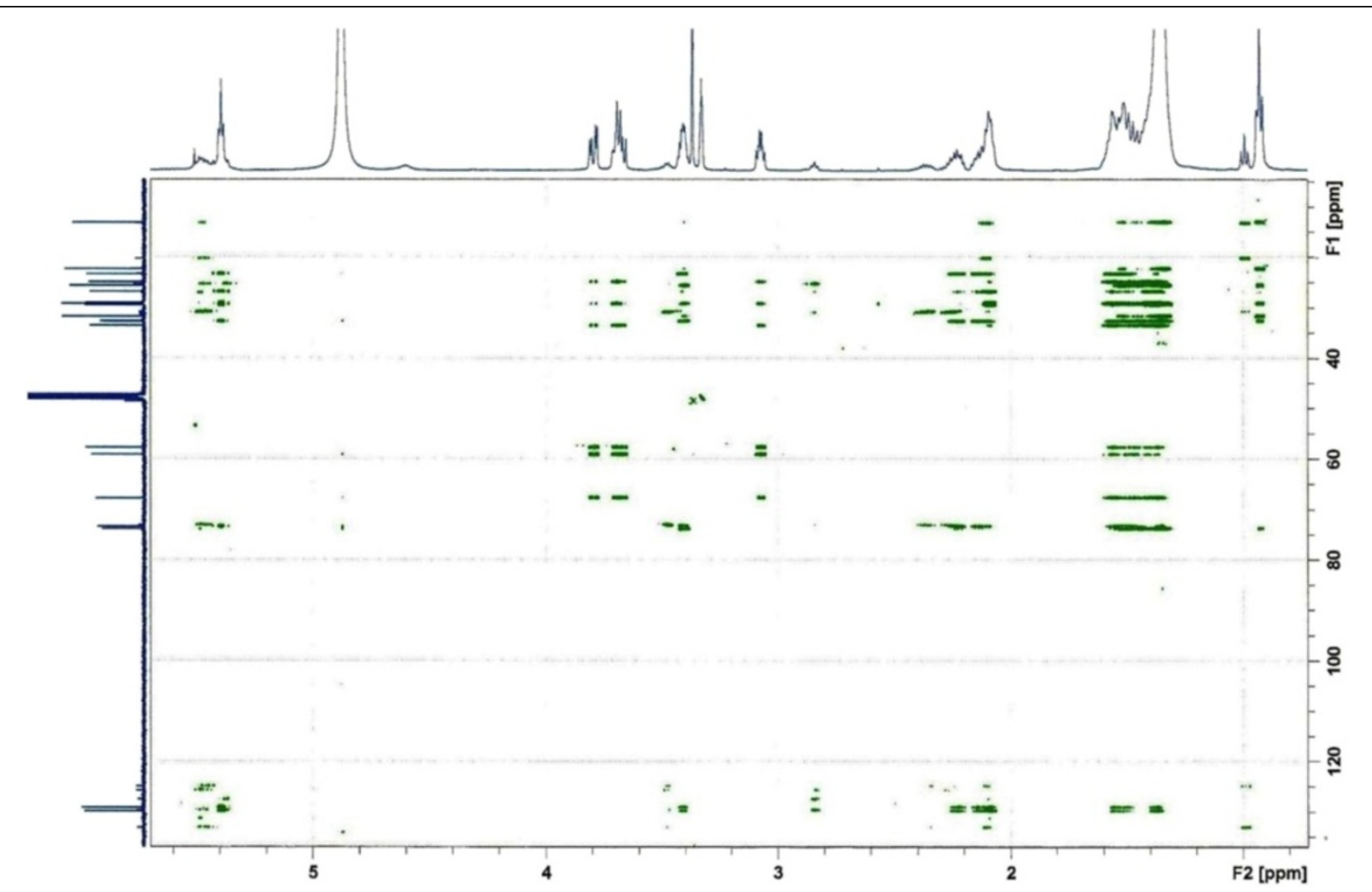

Figure $6 \mathrm{HSQC}$ spectrum of haliscosamine.

\section{Biological activities of haliscosamine Antifungal activity}

In vitro antifungal activity and minimal inhibitory concentration $\left(\mathrm{MIC}_{90}\right)$ of haliscosamine against the pathogenic yeasts were reported in Tables 2 and 3 respectively.

The in vitro antifungal activity by the diffusion method showed that haliscosamine was more active than nystatin in inhibiting the growth of Cryptococcus neoformans (ATCC 11576), but showed the same activity as nystatin in inhibiting the growth of C. albicans (ATCC 10231). On the other hand, haliscosamine was active against C. tropicalis (R2 CIP 1275.81), an amphotericin B and nystatin resistant strain.

The $\mathrm{MIC}_{90}$ of haliscosamine is less than that of nystatin on C. neoformans. and C. albicans, and the same level as the previous in C. tropicalis.

\section{Toxicity test}

Lethality concentration ( $24 \mathrm{~h}-\mathrm{LC}_{50}$ value) for haliscosamine is $664.86 \mu \mathrm{g} / \mathrm{mL}$. This general toxicity activity is considered weak when the $\mathrm{LC}_{50}$ was between 500 and $1000 \mu \mathrm{g} / \mathrm{mL}$, moderate when the $\mathrm{LC}_{50}$ was between 100 and $500 \mu \mathrm{g} / \mathrm{mL}$, and designated as strong when the $\mathrm{LC}_{50}$ ranged from 0 to
$100 \mu \mathrm{g} / \mathrm{mL}$ (Padmaja et al. 2002, Canales et al. 2007). Consequentely, the toxicity of the haliscosamine may be considered as weak by this test.

\section{Discussion}

Haliscosamine isolated from the Moroccan marine sponge Haliclona viscosa is a new derivative of sphingosine with an original molecular structure ((Z)-2-amino-docos-9ene-1,3,13,14-tetraol, $\mathrm{C}_{22} \mathrm{H}_{45} \mathrm{NO}_{4}$ ). However, the relative and absolute stereochemistries of the molecule remain to be determined, with confirmation by total synthesis.

The high content $(0.01 \%)$ of the haliscosamine in the sponge, as its presence in the free state and not involved in a ceramide or other complex lipid is remarkable. The haliscosamine is added to products already isolated from sponges of the genus Haliclona, such the alkaloids viscosamine (Volk and Kock 2003), viscosaline (Volk and Kock 2004) and haliclamines A, B, C and D (Fusetani et al. 1989, Volk et al. 2004). The activity of this product also shows the bioactive potential of marine sponges from the Atlantic Coast of Morocco, and encourages them to continue our sorting activity. The only study that has been done before has been the isolation of untenospongin $\mathrm{B}$ (antimicrobial) from the marine sponge Hippospongia 
Table 1 NMR spectroscopic data for haliscosamine

\begin{tabular}{|c|c|c|c|c|c|c|}
\hline Carbon & $\delta^{13} \mathrm{Cppm}$ & $\delta^{1} \mathrm{H} \mathrm{pl}$ & & HMBC & COSY & TOCSY \\
\hline $1 a$ & $59.12, \mathrm{CH} 2$ & $3.67 \mathrm{dd}$ & $(J=11.7,4.0)$ & 2,3 & $1 b, 2,3$ & 2,3 \\
\hline $1 b$ & & 3.79dd & $(J=11.7,4.0)$ & 2,3 & $1 a, 2,3$ & 2,3 \\
\hline 2 & $57.72, \mathrm{CH}$ & $3.07 \mathrm{~m}$ & $(J=6.8,4.0)$ & $1,3,4$ & 1 & 1,3 \\
\hline 3 & $67.72, \mathrm{CH}$ & $3.69 \mathrm{~m}$ & $(J=6.8,4.0)$ & $1,2,4,5$ & 1,4 & $1,2,4,6$ \\
\hline $4 a$ & $33.51, \mathrm{CH} 2$ & $1.47 \mathrm{~m}$ & & $2,3,5$ & & \\
\hline $4 b$ & & $1.57 \mathrm{~m}$ & & $2,3,5$ & & \\
\hline $5 a$ & $24.92, \mathrm{CH} 2$ & $1.40 \mathrm{~m}$ & & 3 & & \\
\hline $5 b$ & & $1.57 \mathrm{~m}$ & & 3 & & \\
\hline 6 & $28.94, \mathrm{CH} 2$ & $1.37 \mathrm{~m}$ & & & & \\
\hline 7 & $29.45, \mathrm{CH} 2$ & $1.37 \mathrm{~m}$ & & 8 & 8 & 9 \\
\hline 8 & 26.77, $\mathrm{CH} 2$ & $2.09 \mathrm{~m}$ & & 7,9 & $7,9,10$ & \\
\hline 9 & $129.08, \mathrm{CH}$ & $5.39 \mathrm{~m}$ & & 8 & 8,10 & 8,7 \\
\hline 10 & $129.82, \mathrm{CH}$ & $5.40 \mathrm{~m}$ & & 11 & $8,9,11$ & 11,13 \\
\hline $11 a$ & 23.32, $\mathrm{CH} 2$ & $2.13 \mathrm{~m}$ & & $10,12,13$ & 10,12 & 10,13 \\
\hline $11 b$ & & $2.24 \mathrm{~m}$ & & $10,12,13$ & 10,12 & 10,13 \\
\hline $12 a$ & $32.59, \mathrm{CH} 2$ & $1.54 \mathrm{~m}$ & & 11,13 & & 13 \\
\hline $12 b$ & & $1.59 \mathrm{~m}$ & & 11,13 & & 13 \\
\hline 13 & 73.37, $\mathrm{CH}$ & 3.42 & & $11,12,14,15$ & & $10,11,12,15$ \\
\hline 14 & $73.81, \mathrm{CH}$ & 3.40 & & $13,15,16$ & 15 & \\
\hline $15 a$ & $32.67, \mathrm{CH} 2$ & $1.44 \mathrm{~m}$ & & $13,14,16$ & 14 & 13 \\
\hline $15 b$ & & $1.54 \mathrm{~m}$ & & $13,14,16$ & 14 & 13 \\
\hline $16 a$ & $25.64, \mathrm{CH} 2$ & $1.37 \mathrm{~m}$ & & 14,15 & & \\
\hline $16 b$ & & $1.52 \mathrm{~m}$ & & 14,15 & & \\
\hline 17 & $29.17, \mathrm{CH} 2$ & $1.37 \mathrm{~m}$ & & & & \\
\hline 18 & $29.18, \mathrm{CH} 2$ & $1.37 \mathrm{~m}$ & & & & \\
\hline 19 & $29.20, \mathrm{CH} 2$ & $1.37 \mathrm{~m}$ & & & & \\
\hline 20 & $31.66, \mathrm{CH} 2$ & $1.33 \mathrm{~m}$ & & 21,22 & & \\
\hline 21 & $22.32, \mathrm{CH} 2$ & $1.36 \mathrm{t}$ & $(J=6.5)$ & 20,22 & & \\
\hline 22 & $13.06, \mathrm{CH} 3$ & 0.92 & & 20,21 & & \\
\hline
\end{tabular}

communis (Rifai et al. 2004) and of fasciculatin (cytotoxic and inhibitor of lymphocyte proliferation) isolated from Ircinia variabilis (Rifai et al. 2005).

Haliscosamine has a remarkable antifungal effect. Sphingolipids are already known for their antiseptic and antifungal activity (Bibel et al. 1995), and sphingosine and its derivatives are natural antimicrobial agents, protecting the human skin from bacterial colonization (Bibel et al. 1993) as well as being anti-inflammatory agents (Radhika et al. 2005).

Compared to nystatin, haliscosamine showed in vitro significant activity against Candida albicans (ATCC 10231), Candida tropicalis (CIP 1275.81) and Cryptococcus neoformans (ATCC 11576). These three yeasts are often involved in human mycology especially $C$. tropicalis that is resistant to nystatin and amphotericin $B$.
Comparing the antifungal activity of haliscosamine with (-)-untenospongin B isolated from the marine sponge Hippospongia communis collected from the Atlantic Coast of Morocco (Rifai et al. 2004), it was found that haliscosamine was more active than untenospongin $B$ in inhibiting the growth of C. tropicalis (R2 CIP 1275.81), C. albicans (ATCC 10231) and C. neoformans (ATCC 11576) (Table 2). So, haliscosamine is an interesting product, thanks to its antifungal potential against strains involved in human mycology, including those resistant to nystatin. Further studies are still needed to determine in vivo activity and toxicity of haliscosamine in the animal model as well as to elucidate the mechanism underlying its activity. The lethal concentration $\left(24 \mathrm{~h}-\mathrm{LC}_{50}=664.86 \mu \mathrm{g} / \mathrm{mL}\right)$ of haliscosamine is greater than $500 \mu \mathrm{g} / \mathrm{mL}$, so the general toxicity activity was regarded weak. Therefore, if the 


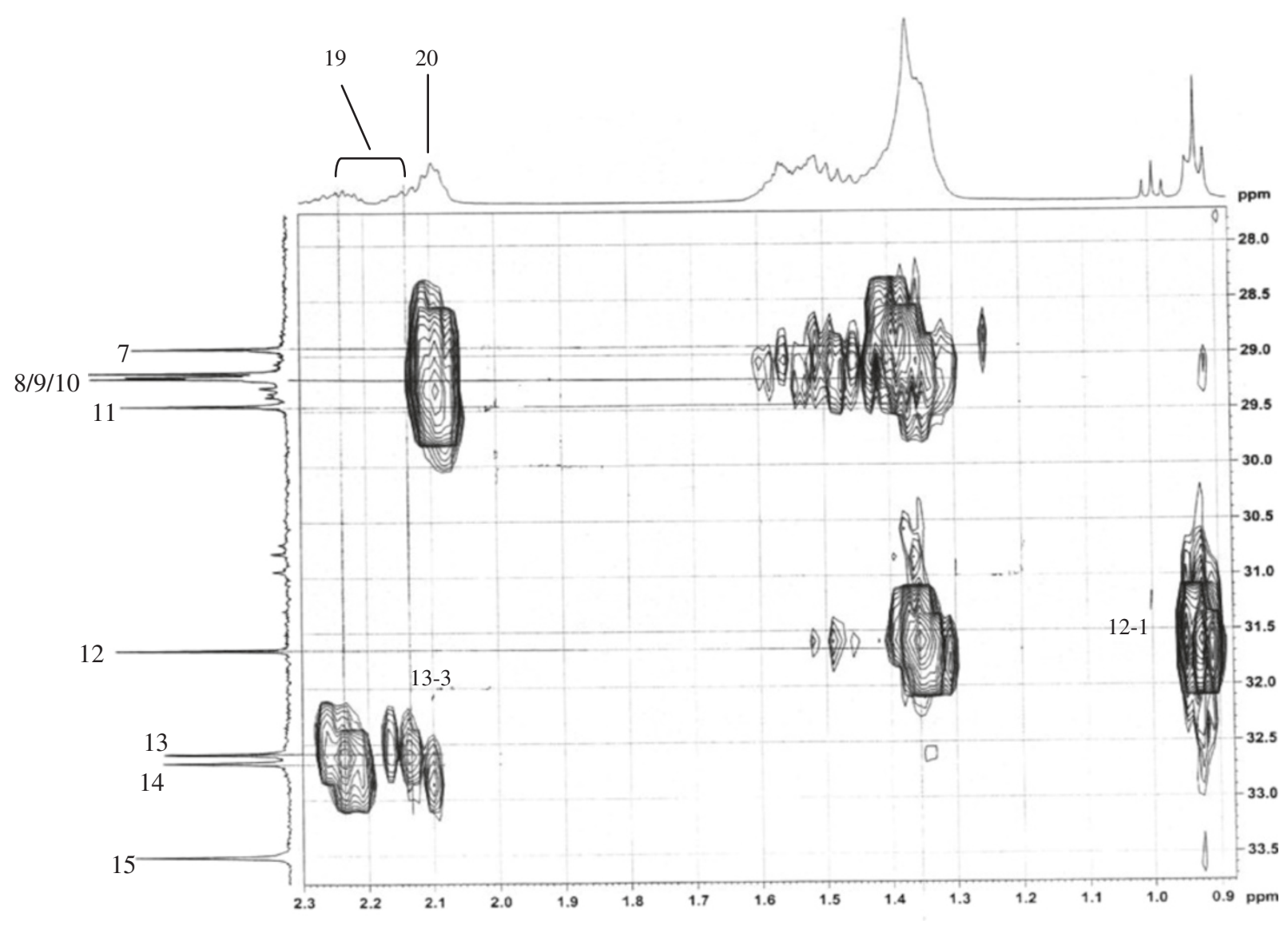

Figure $7{ }^{1} \mathrm{H}-{ }^{13} \mathrm{C}$ HMBC spectrum of haliscosamine (MEOD).

activity persists in vivo, then the product could be a candidate to assess more fully for a development of a new drug for the treatment of fungal infections.

\section{Materials and methods}

\section{Biological marine material}

The marine sponge (Ref. EM14) H. viscosa (Topsent, 1888) was collected from the Atlantic coast of El-Jadida city, Morocco (N $33 \quad 15$ 422, W $008^{\circ} 29$ 722) (El-Amraoui et al. 2010). The sponge was identified by Dr. Maria-Jesús Uriz, Research Professor at the Centro de Estudios Avanzados de Blanes(CEAB), Spain. After collection, the sponge was immediately cut into small pieces, washed with sterile distilled water, then frozen at $-30^{\circ} \mathrm{C}$ for two days and immediately freeze-dried to give a lyophilized material ready for extraction.

\section{General experimental procedures}

Freeze-dryer was a FreeZone2.5Plus type (Labconco, USA).
TLC was carried out on precoated Macherey-Nagel Alugram silica, and spots were visualized by spraying with iodine vapor or ninhydrine reagents.

The UV spectrum was recorded on a Helios Omega spectrophotometer (Thermo Scientific, France).

The IR spectrum was obtained on a spectrometer IR-FT Paragon 1000 PC (Perkin-Elmer, USA).

The NMR spectra $\left({ }^{1} \mathrm{H},{ }^{13} \mathrm{C}, \mathrm{HSQC}, \mathrm{HMBC}, \mathrm{COSY}\right.$ and TOCSY experiments) were recorded on a Bruker 500 with a TXI cryosonde (PRISM, Rennes University, France) and a Bruker Avance 500 (CRMPO, Rennes University, France) for in-deep 2D experiments and irradiations tests.

HRESIMS data were recorded on a Micromass Zab Spec Tof (CRMPO, Rennes University, France). ESIMS data of the acetylated product was recorded on a Finnigan LCQ mass spectrometer (IFREMER, Nantes, France).

Optical rotation was measured on a Schmidt + Haensch Polartronic NH8 polarimeter.

Acetylation: $1 \mathrm{mg}$ of isolated product was treated with $1 \mathrm{~mL}$ of acetic anhydride $\left(\mathrm{Ac}_{2} \mathrm{O}\right)$ :pyridine $(1: 1 \mathrm{v} / \mathrm{v})$ for 

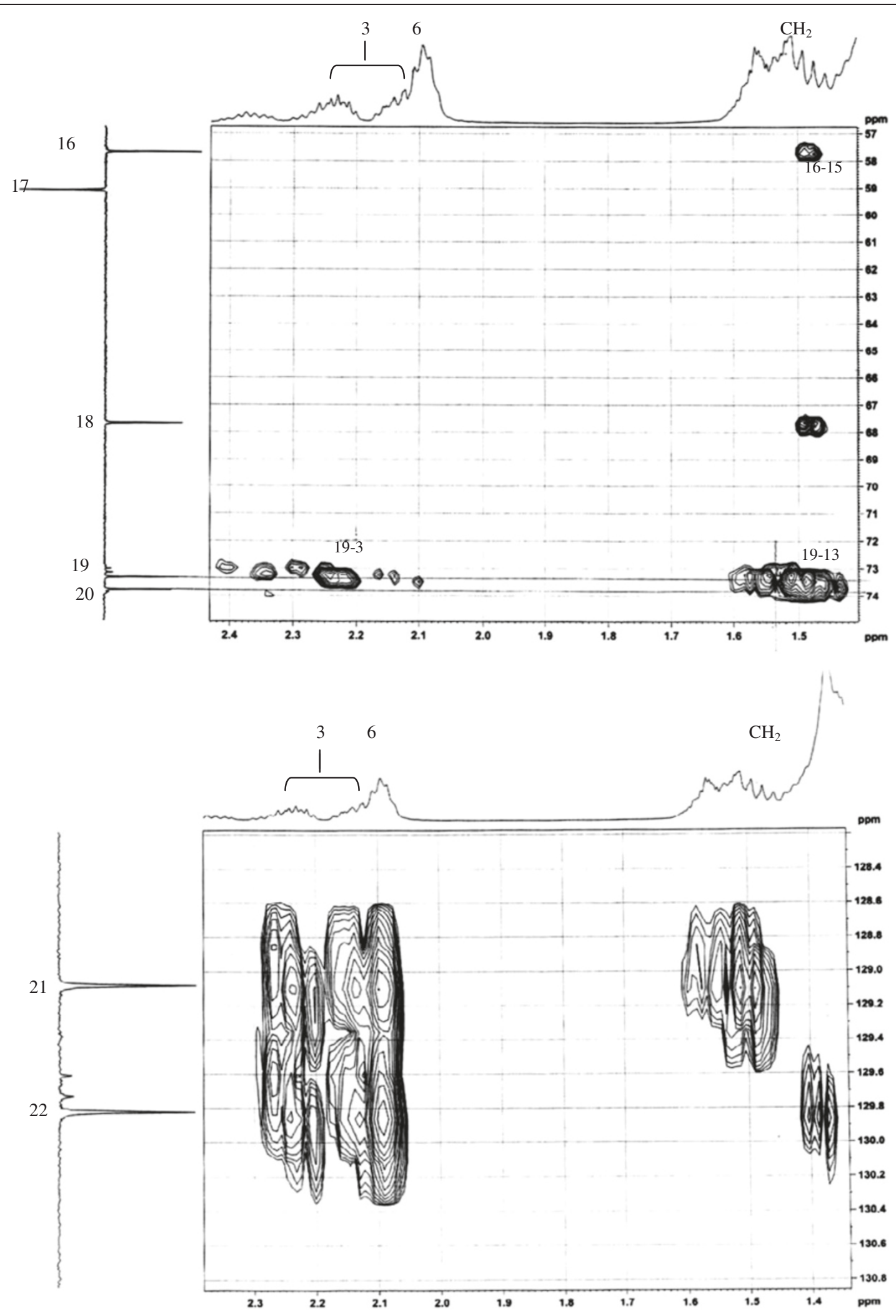

Figure $8{ }^{1} \mathrm{H}-{ }^{13} \mathrm{C}$ HMBC spectrum of haliscosamine (MEOD). 


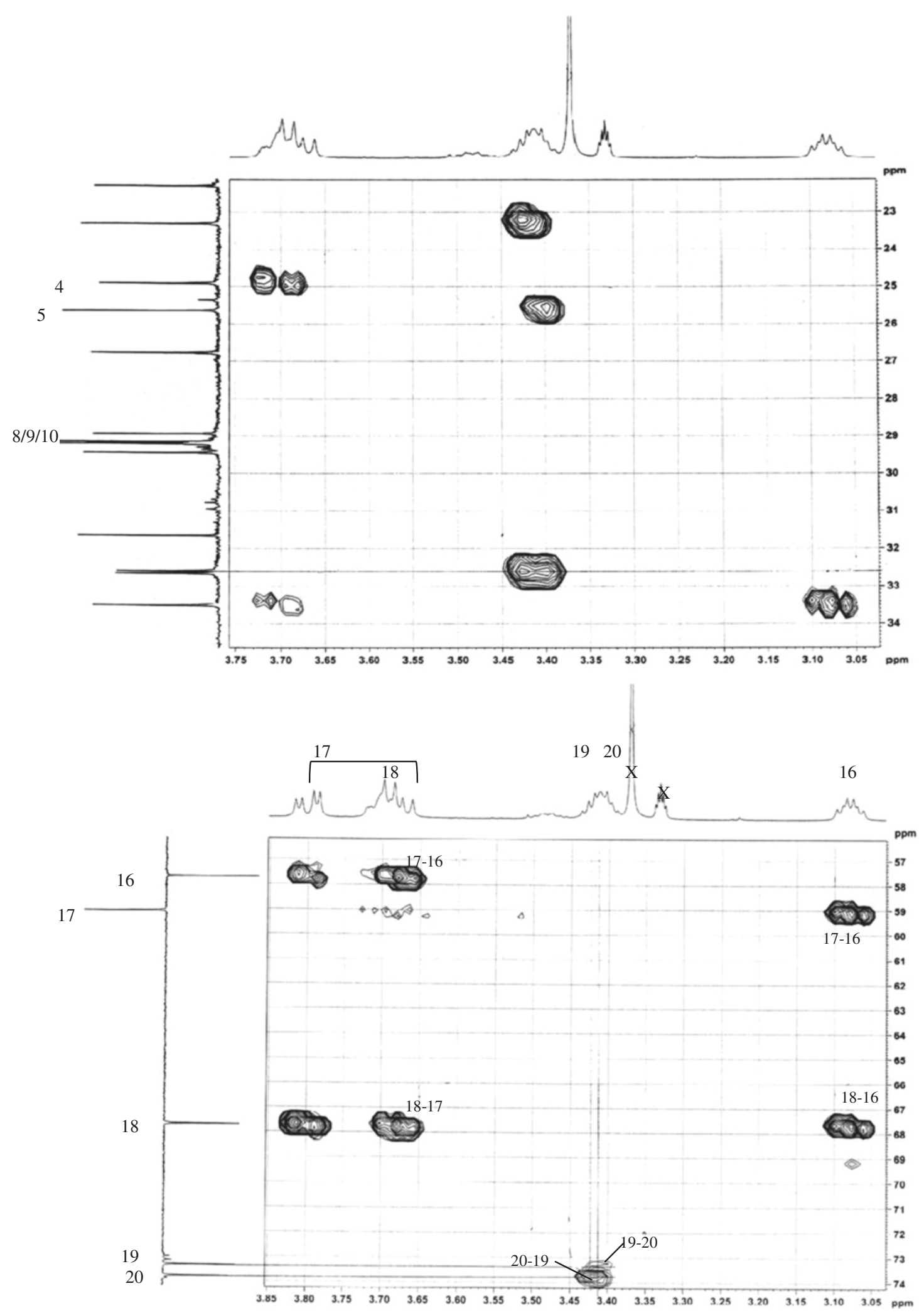

Figure $9{ }^{1} \mathrm{H}-{ }^{13} \mathrm{C}$ HMBC spectrum of haliscosamine (MEOD). 


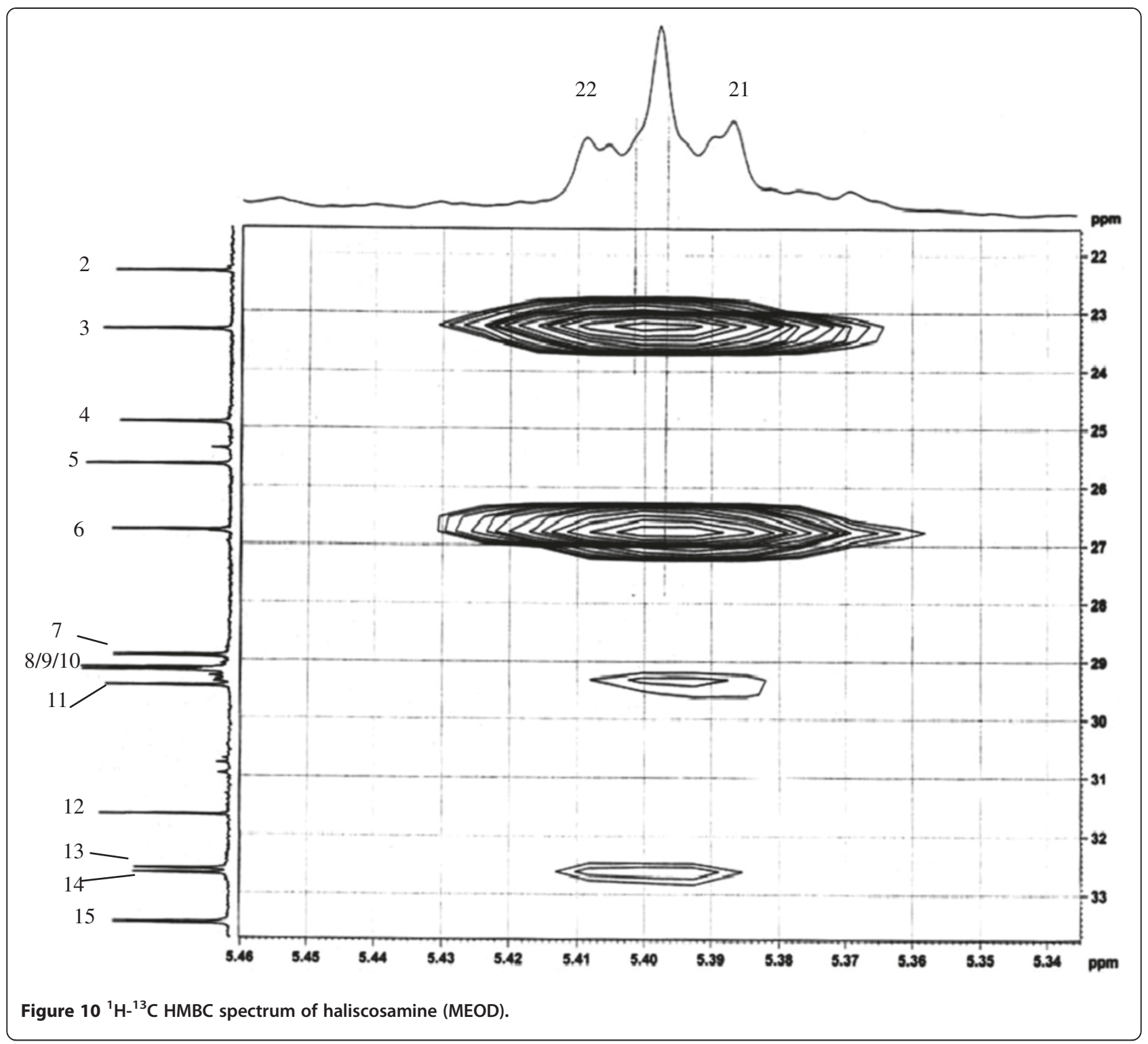

$24 \mathrm{~h}$ at ambient temperature, then $40 \mathrm{~mL}$ of $+4^{\circ} \mathrm{C}$ water was added and the mixture extracted with diethyl-ether $(4 \times 10 \mathrm{~mL})$ to afford $1.2 \mathrm{mg}$ of acetylated product.

\section{Extraction and isolation}

The sample (800 g of lyophilized sponge) was homogenized with ethanol $80 \%(1 \times 1000 \mathrm{~mL})$, allowed to stand in a dark chamber for $24 \mathrm{~h}$ and filtered. The residue was again extracted with absolute ethanol $(2 \times 1000 \mathrm{~mL})$. Both ethanolic extracts were combined, and then evaporated at reduced pressure until total evaporation of ethanol. The resulting aqueous suspension was completed with distilled water to $1000 \mathrm{~mL}$ as final volume and extracted with $\mathrm{CH} 2 \mathrm{Cl} 2(3 \times 500 \mathrm{~mL})$. The $\mathrm{CH} 2 \mathrm{Cl} 2$ solutions were combined, dried on anhydrous sodium sulphate (Na2SO4), filtered and concentrated at reduced pressure to give a dichloromethane extract $(3 \mathrm{~g})$.

This extract was fractioned by modified Kupchan method: 3 g were dissolved in $300 \mathrm{~mL}$ of $\mathrm{MeOH}: \mathrm{H}_{2} \mathrm{O}$ (9:1 v/v) and extracted with $3 \times 150 \mathrm{~mL}$ of hexane (A) (1.5 g). The remaining solution was adjusted with distilled water to get the proportions $6: 4 \mathrm{v} / \mathrm{v}$, then extracted with $3 \times 150 \mathrm{~mL}$ of dichloromethane (B) $(0.3 \mathrm{~g})$ and then with $3 \times 150 \mathrm{~mL}$ of ethyl acetate $(\mathrm{C})(0.7 \mathrm{~g})$. The residue was lyophilized (D) (0.5 g).

Fractions C and D were combined (1.2 g), applied on silica gel 60 (25 g) column, and eluted with successive mixtures $(110 \mathrm{~mL})$ of $\mathrm{CHCl}_{3}: \mathrm{MeOH}(10: 0 ; 9: 1 ; 8: 2 ; 7: 3$; $6: 4 ; 4: 6$ and $0: 10 \mathrm{v} / \mathrm{v}$ ) to yield nine fractions. Fractions 4,5 


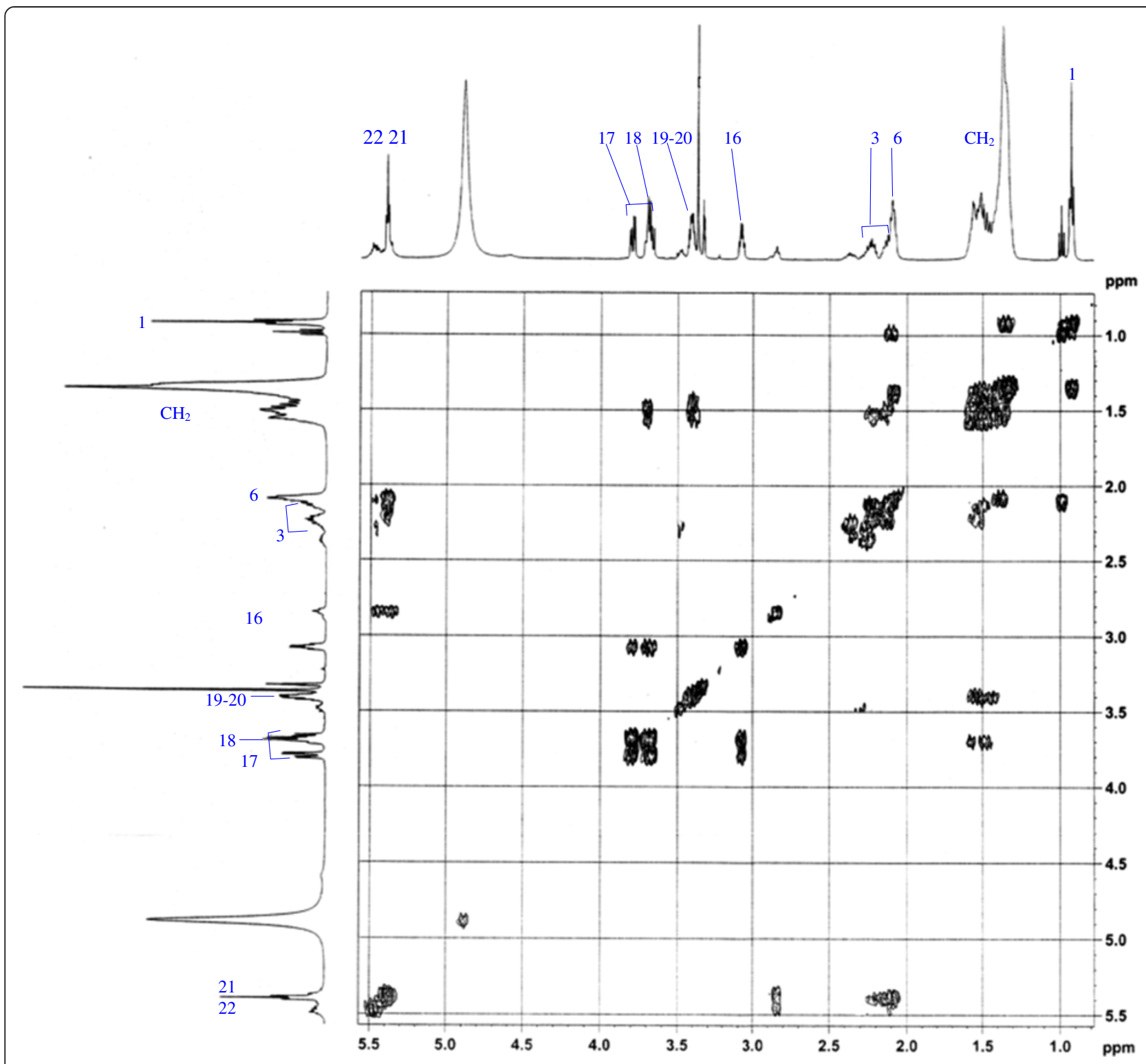

Figure $11{ }^{1} \mathrm{H}-{ }^{1} \mathrm{H}$ COSY spectrum of haliscosamine.

and 6 were pooled $(260 \mathrm{mg})$, then separated on a semipreparative HPLC diol column (Inertsil Diol L10OH.25R, $10 \times 250 \mathrm{~mm}, 10 \mu \mathrm{m})$ by a $\mathrm{CH}_{2} \mathrm{CL}_{2}: \mathrm{MeOH}(8.5: 1.5 \mathrm{v} / \mathrm{v})$ isocratic mixture. Purification of subfractions $2(95 \mathrm{mg})$ by HPLC C18 column (Inertsil ODS-3, $4.6 \times 250 \mathrm{~mm}, 5 \mu \mathrm{m}$ ) with isocratic $\mathrm{MeOH}: \mathrm{H}_{2} \mathrm{O}(6.5: 3.5 \mathrm{v} / \mathrm{v})$ gave $47 \mathrm{mg}$ of a pure active product.

\section{Microorganisms}

The fungal species obtained from the Fungi Culture Collection (FCC) of the National Cultures Collection of Microorganisms of the Pasteur Institute, Paris, France, from the Collection of Institut Pasteur (CIP) and from the American Type Culture Collection (ATCC) were used as the antifungal test strains: Candida albicans (ATCC 10231), Candida tropicalis (R2 CIP 1275.81, an amphotericin B and nystatin resistant strain), Cryptococcus neoformans (ATCC 11576). The yeasts were maintained on the Sabouraud's agar medium at $28^{\circ} \mathrm{C}$.

\section{Antifungal activity}

The antifungal activity was assessed in vitro by agar discdiffusion test. The minimum inhibitory concentration was evaluated by the microdilution method. 


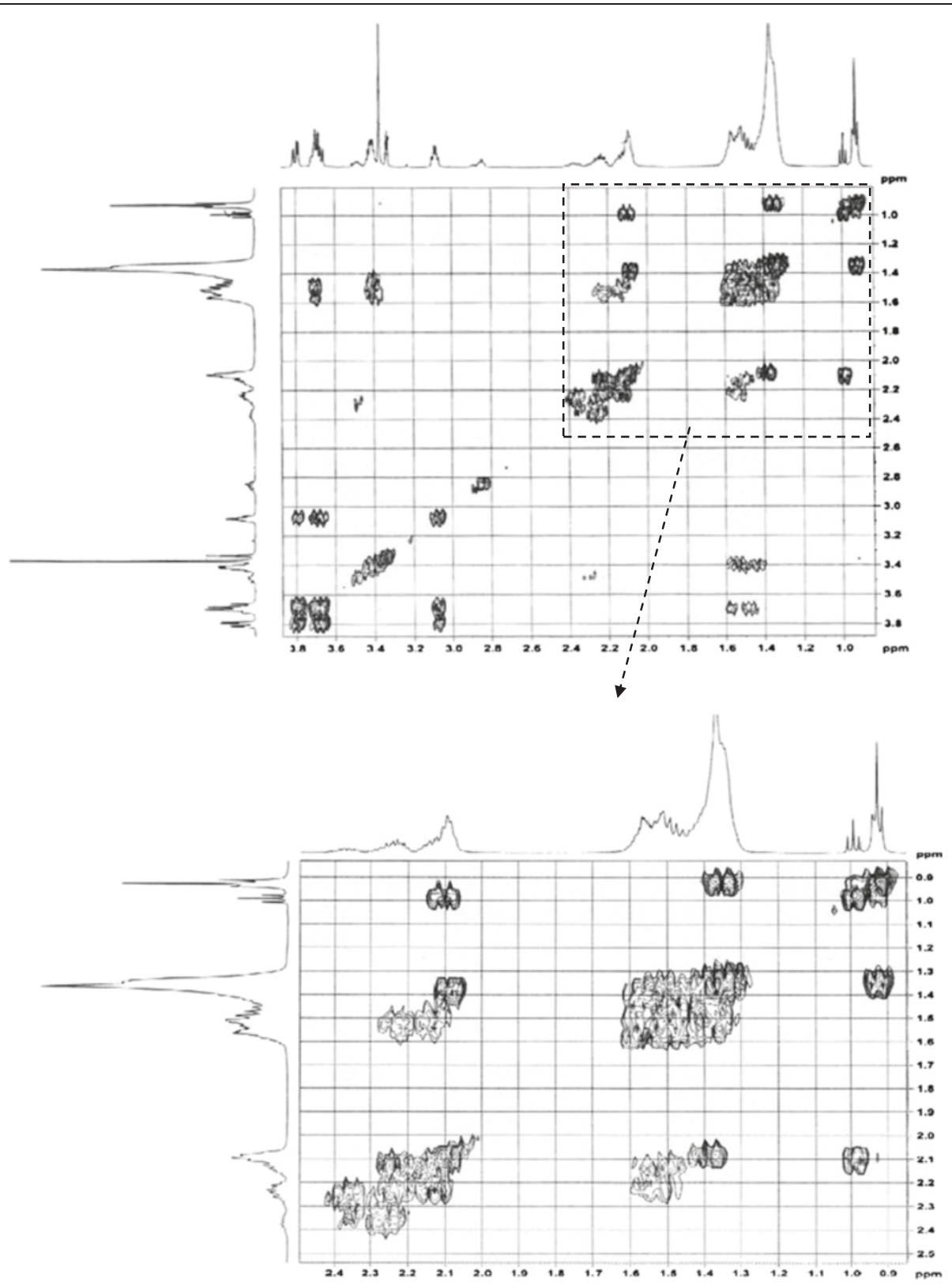

Figure 12 Detail of ${ }^{1} \mathrm{H}-{ }^{1} \mathrm{H}$ COSY spectrum of haliscosamine.

\section{Agar disc-diffusion test}

This test uses Yeast Morphological Agar (YMA) as medium [yeast nitrogen base (Difco) $60.5 \mathrm{~g} / \mathrm{L}$; asparagin (Prolabo) $1.5 \mathrm{~g} / \mathrm{L}$; glucose (Merck) $10 \mathrm{~g} / \mathrm{L}$ and agar (Merck) $20 \mathrm{~g} / \mathrm{L}]$. The suspensions of yeast were adjusted in sterile water to match the density of a 0.5 McFarland Standard. Each disk received $100 \mu \mathrm{g}$ of sponge extract and was applied on the test media which were previously inoculated with each test strain. Plates were first kept at $4^{\circ} \mathrm{C}$ for at least two hours to allow the diffusion of chemicals, and then incubated at $28^{\circ} \mathrm{C}$. Inhibition zones were measured after $24 \mathrm{~h}$ of incubation (Galeano and Martínez 2007). Standard disks of nystatin $(100 \mu \mathrm{g})$ served as positive antifungal control. All the assays were carried out in triplicate.

\section{Minimum inhibitory concentration (MIC)}

The $\mathrm{MIC}_{90}$ (the lowest concentration causing at least $90 \%$ of growth inhibition when compared to drug-free control) of the isolated compound was measured using the method described by Rifai et al. (2005). Yeast Morphological Broth medium was used as test media. Tests 


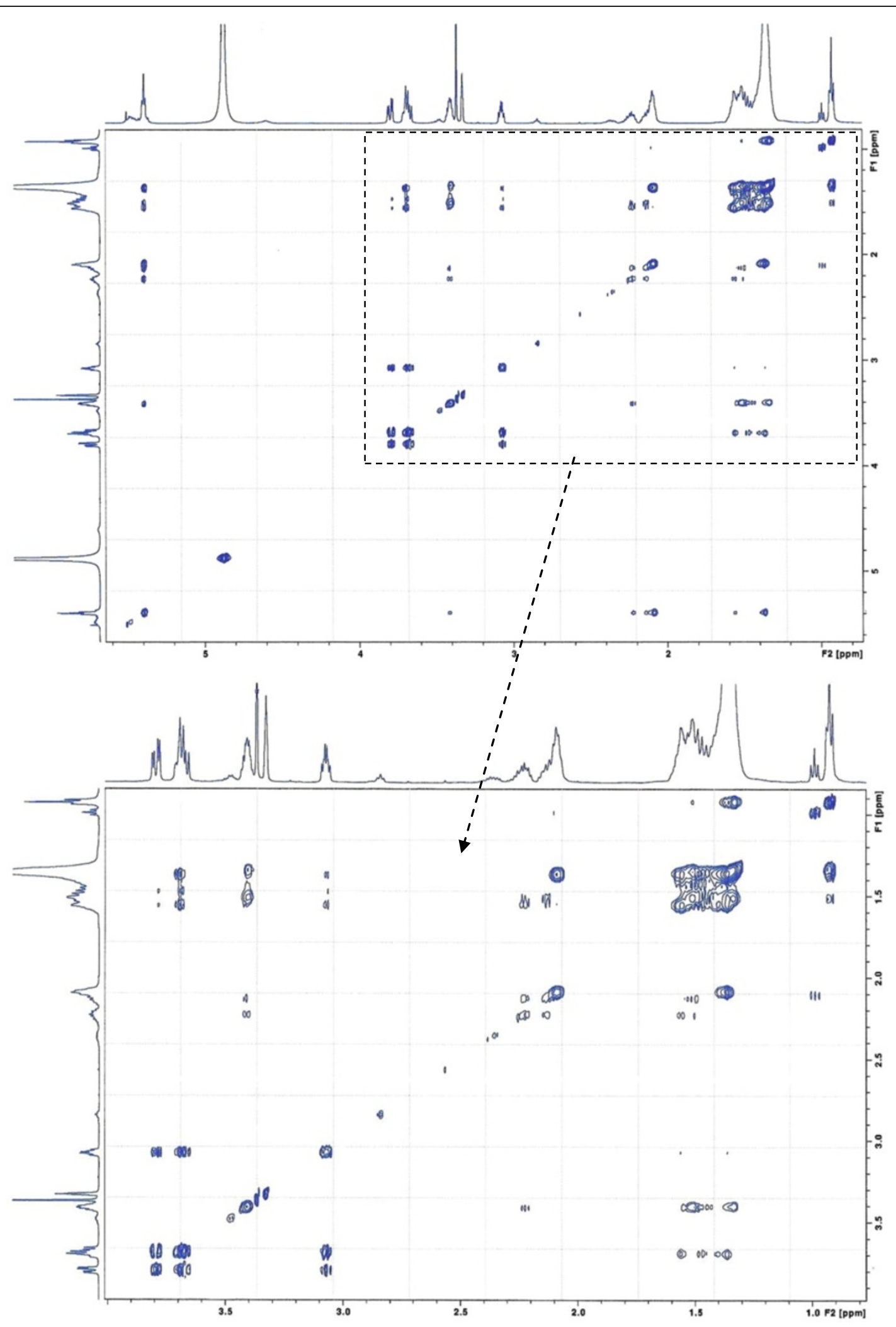

Figure 13 TOCSY spectrum of haliscosamine. 


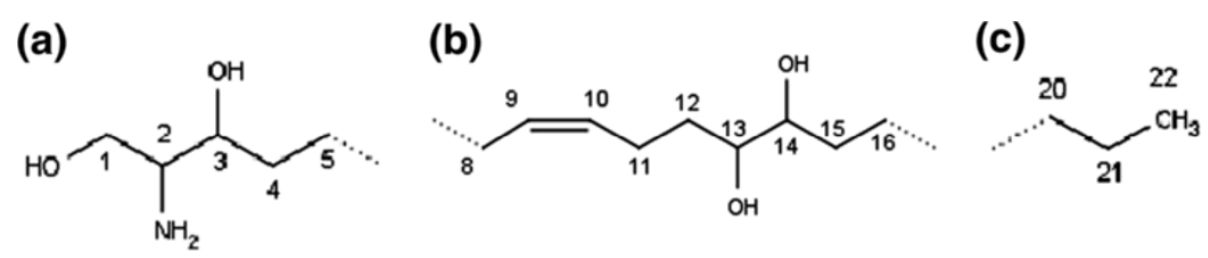

Figure 14 The three sub-structures of haliscosamine. (a) C-1 to C-6, (b) C-8 and C-16 (c) C-20 to C-22.

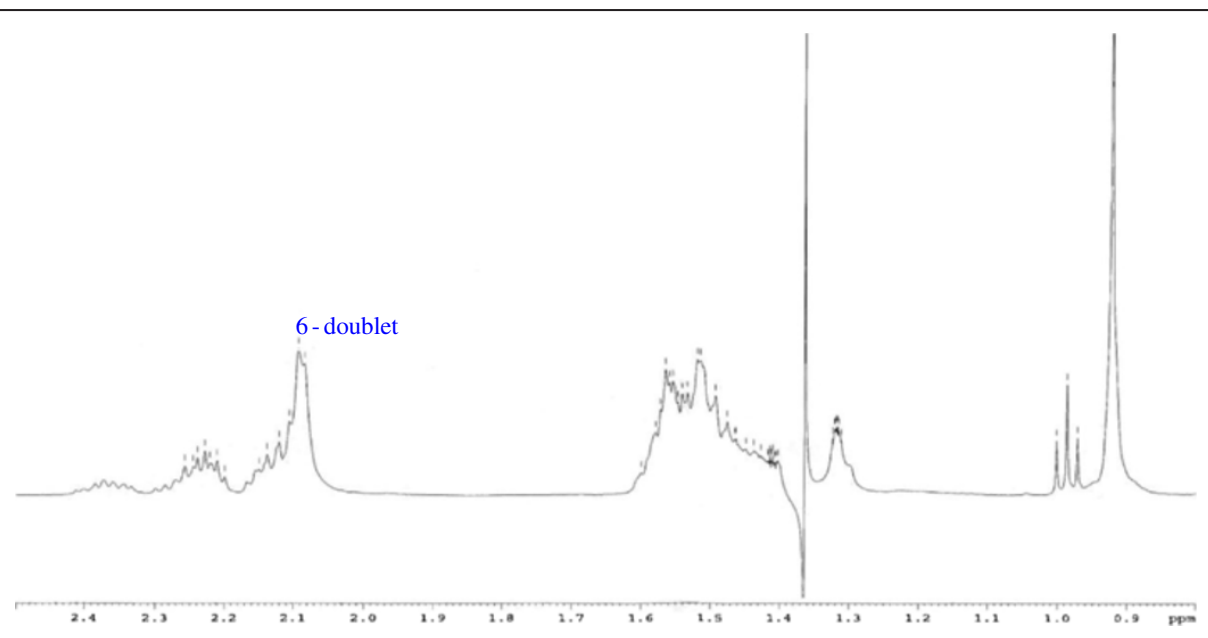

Figure $15^{1} \mathrm{H}$ spectrum of haliscosamine (MEOD, irradiation at $\delta 1.369 \mathrm{ppm}$ ).

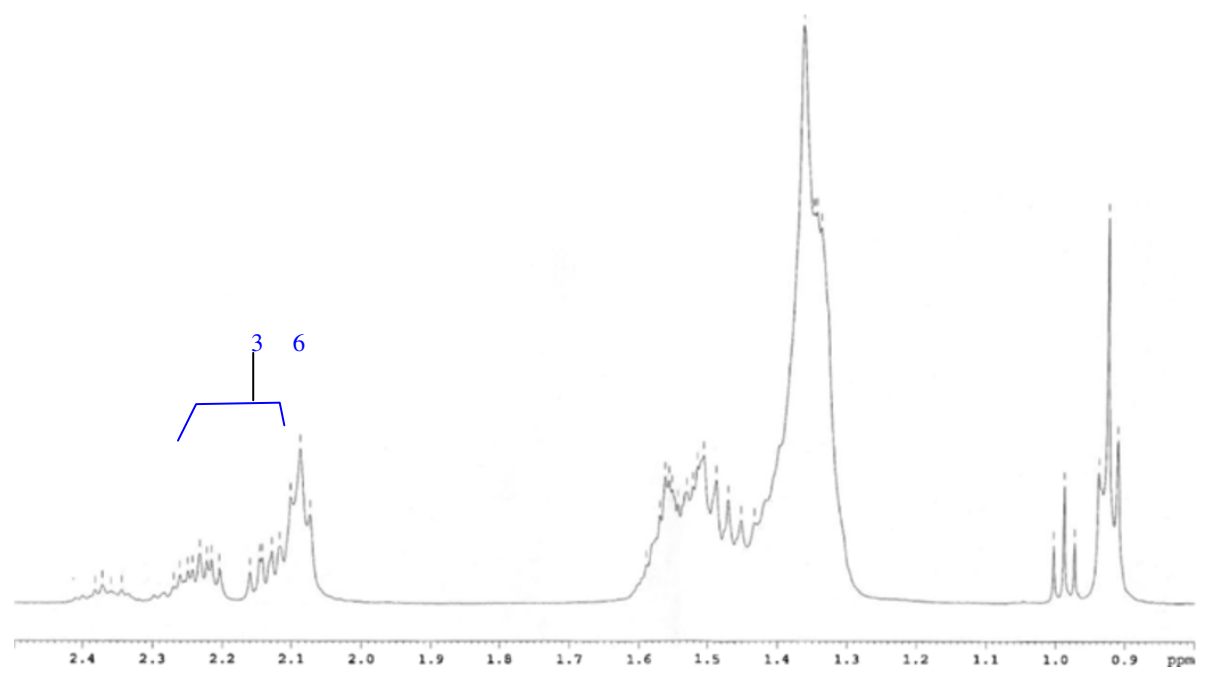

Figure $16^{1} \mathrm{H}$ spectrum of haliscosamine (MEOD, irradiation at $\delta 5.398 \mathrm{ppm}$ ). 


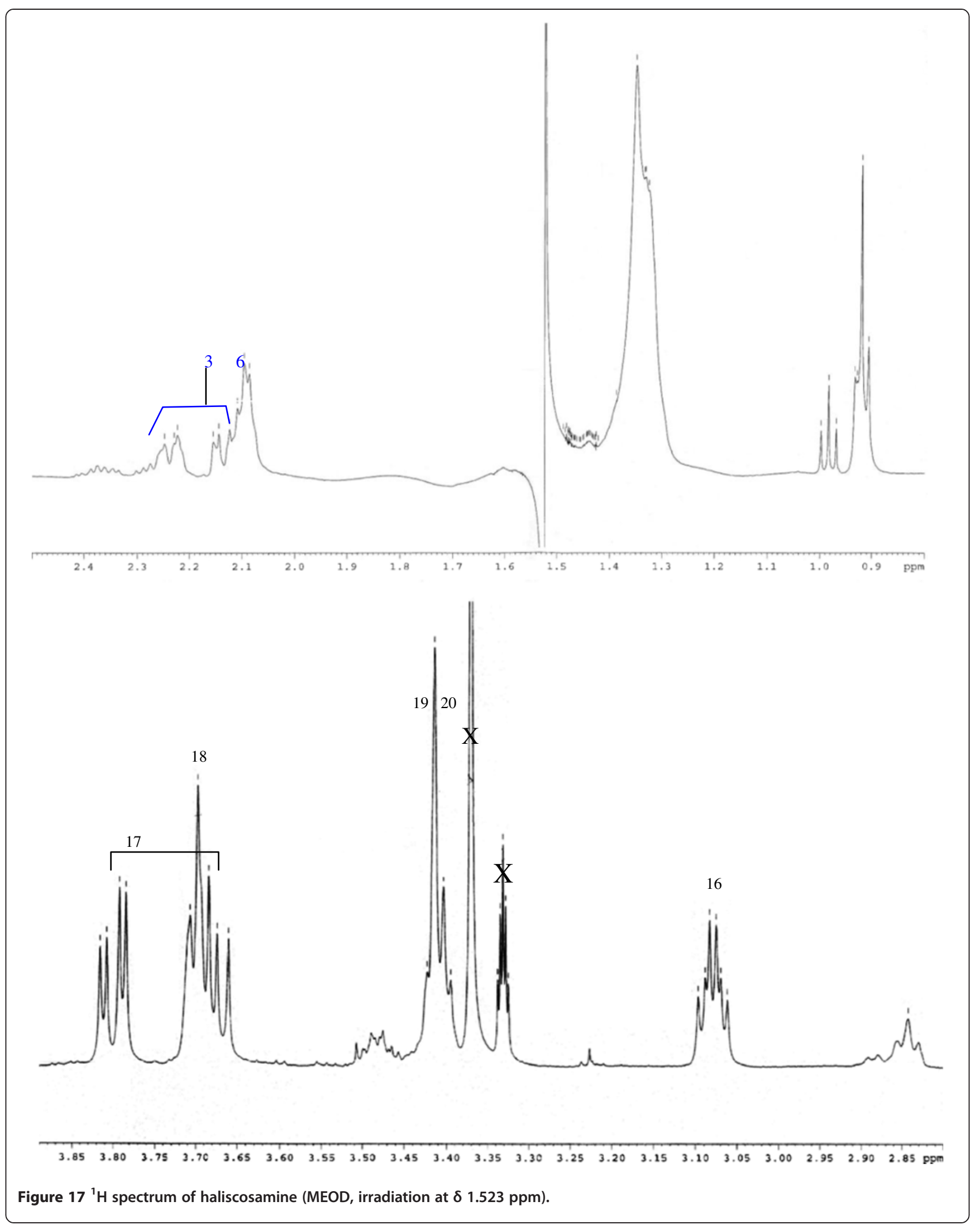




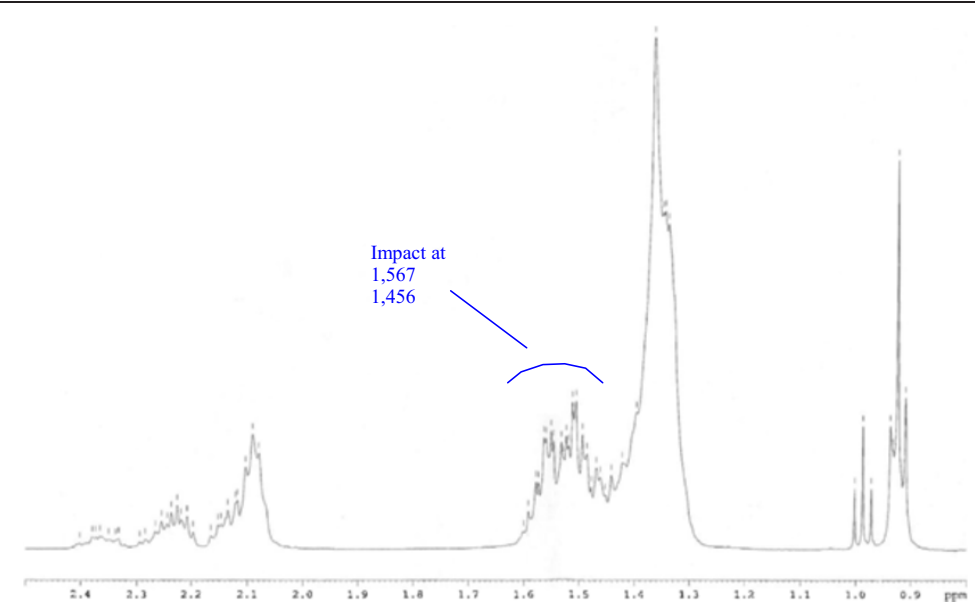

Figure $18^{1} \mathrm{H}$ spectrum of haliscosamine (MEOD, irradiation at $\delta 3.415 \mathrm{ppm}$ ).
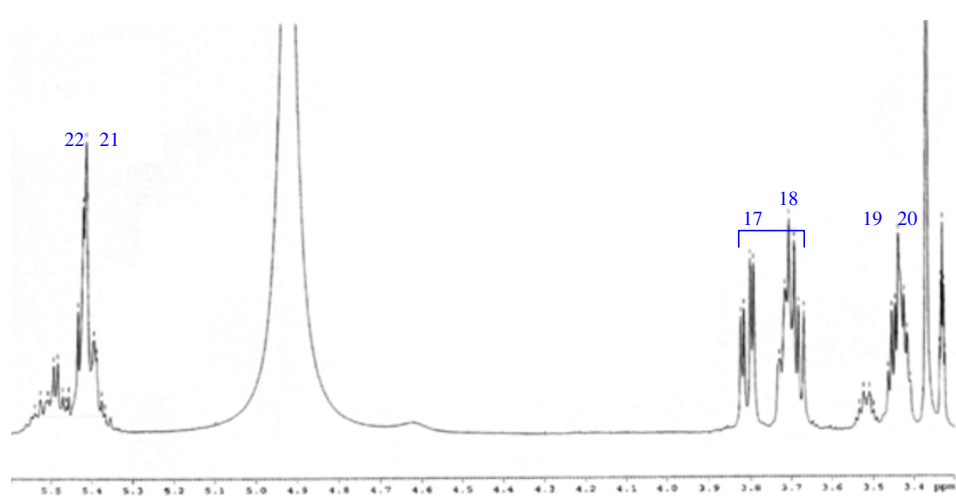

Figure $19{ }^{1} \mathrm{H}$ spectrum of haliscosamine (MEOD, irradiation at $\delta 2.09$ ).

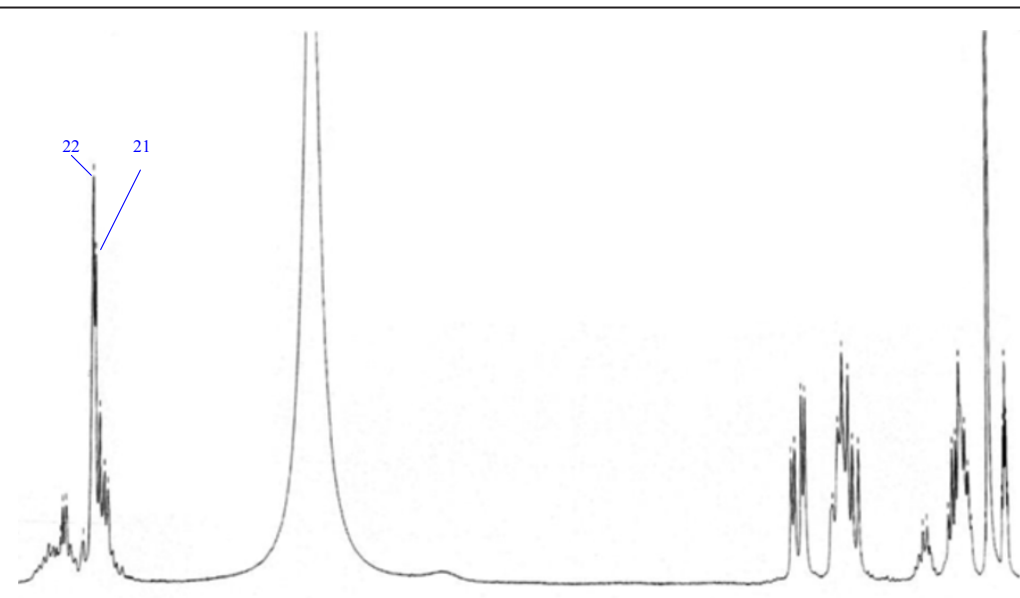

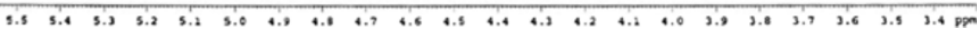

Figure $20{ }^{1} \mathrm{H}$ spectrum of haliscosamine (MEOD, irradiation at $\delta$ 2.28). 

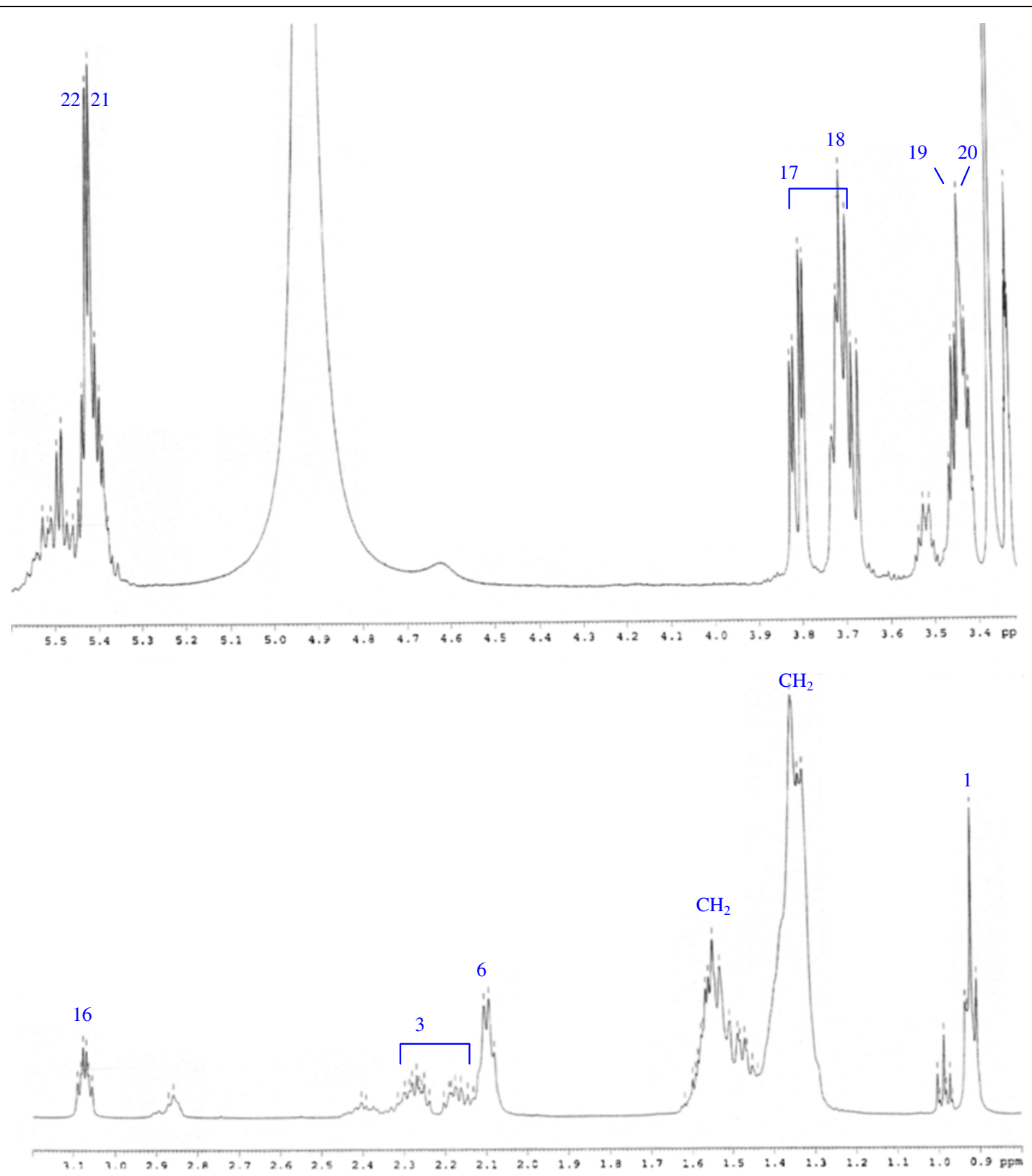

Figure $21^{1} \mathrm{H}$ NMR spectrum of haliscosamine (CD3OD + few drops of C6D6).

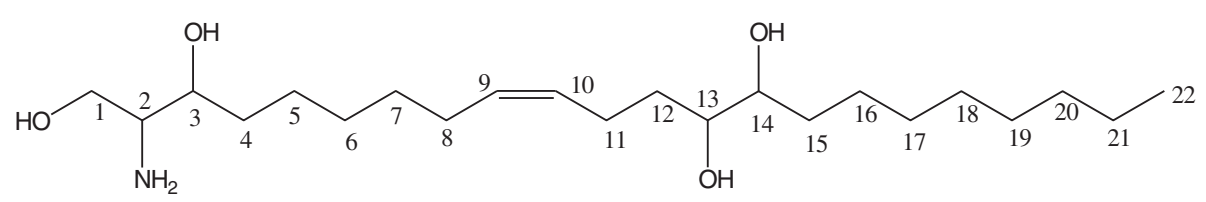

Figure 22 Molecular structure of haliscosamine [(9Z)-2-amino-docos-9-ene-1,3,13,14-tetraol]. 
Table 2 In vitro antifungal activity of haliscosamine and nystatin against pathogenic yeasts

\begin{tabular}{|c|c|c|c|}
\hline \multirow[t]{2}{*}{ Test organism } & \multicolumn{3}{|c|}{ Growth inhibition diameter $(\mathrm{mm})$} \\
\hline & $\begin{array}{l}\text { Haliscosamine } \\
(100 \mu \mathrm{g})\end{array}$ & $\begin{array}{l}\text { Nystatin } \\
(100 \mu g)\end{array}$ & $\begin{array}{l}\text { (-)-untenospongin } \\
\mathrm{B}(100 \mu \mathrm{g})\end{array}$ \\
\hline C. neoformans & 28 & 24 & 0 \\
\hline C. albicans & 25 & 25 & 17 \\
\hline C. tropicalis & 25 & 0 & 5 \\
\hline
\end{tabular}

were performed in 96-well round bottom sterile culture plates. The suspensions of yeast were adjusted in sterile water to match the density of a 0.5 McFarland Standard. The wells of a microdilution plate were inoculated with $180 \mathrm{~mL}$ of the culture medium containing a final inoculum of $0.5-2.510^{3} \mathrm{CFU} / \mathrm{mL}$. The test drug and positive control (nystatin) previously solubilized in dimethylsulphoxide (DMSO) were serially diluted two fold in the liquid medium to give a range of concentration from 640 to $0.1 \mu \mathrm{g} / \mathrm{mL}$. Twenty $\mu \mathrm{L}$ of each concentration were added to wells containing culture suspension except the growth control well. The final concentration ranged from 64 to $0.01 \mu \mathrm{g} / \mathrm{mL}$. Plates were incubated at $35^{\circ} \mathrm{C}$ for $48 \mathrm{~h}$. Fungal growth was assessed at $494 \mathrm{~nm}$ by measuring the optical density in each well using an enzyme immunoassay multiwell reader (Sigma diagnostic). The test was carried out in triplicate.

\section{Brine shrimp toxicity test Hatching shrimp}

Brine shrimp eggs (Artemia salina) are hatched in artificial seawater prepared by dissolving sea salt in distilled water $(38 \mathrm{~g} / \mathrm{L})$ during $48 \mathrm{~h}$ incubation in a warm room $\left(22-29^{\circ} \mathrm{C}\right)$. Seawater is placed in a small unequally divided tank and shrimp eggs are added to the larger compartment of the tank which is covered by aluminium foil to darken it. The illuminated compartment attracts shrimp larvae (nauplii) through perforations in the dam (Meyer et al. 1982).

\section{Brine shrimp microwell toxicity assay}

The toxicity of haliscosamine was monitored by the brine shrimp lethality test. Samples were dissolved in DMSO and diluted with sea water so that the final

Table 3 Minimum Inhibitory Concentration (MIC $\mathrm{Co}_{\mathbf{9 0}}$ ) of haliscosamine and nystatin against pathogenic yeasts

\begin{tabular}{lll}
\hline Test organism & \multicolumn{2}{l}{ Minimum inhibitory concentration $(\boldsymbol{\mu g} / \mathbf{m L})$} \\
\cline { 2 - 3 } & Haliscosamine & Nystatin \\
\hline C. neoformens & $0.2-0.4$ & $3.12-6.25$ \\
C. albicans & $0.4-0.8$ & $3.12-6.25$ \\
C. tropicalis & $0.4-0.8$ & 0 \\
\hline
\end{tabular}

concentration of DMSO did not exceed $0.05 \%$. Serial dilutions $(2000,200$ and $20 \mu \mathrm{g} / \mathrm{mL}$ ) of samples were made in wells of 96-well microplates in triplicate in $100 \mu \mathrm{L}$ of sea water (Rahman et al. 2001). The last row was left with sea water and DMSO only served as the drug free control. $100 \mu \mathrm{L}$ of suspension of nauplii containing about 10 larvae were added into each well and incubated for $24 \mathrm{~h}$ at $22-29^{\circ} \mathrm{C}$. The plates were then examined under a binocular microscope $(\times 12.5)$ and the number of dead nauplii in each well was counted. One hundred $\mu \mathrm{L}$ of methanol were then added and after $10 \mathrm{~min}$, the total numbers of shrimp in each well was counted and recorded. Lethality concentration fifties $\left(\mathrm{LC}_{50}\right.$ values) for each assay were calculated by taking the average of the three experiments using a Finney Probit analysis program on an IBM computer.

\section{Competing interest}

All authors declare that they have no competing interest.

\section{Authors' contributions}

All authors read and approved the final manuscript.

\section{Acknowledgements}

We thank Dr. Maria-Jesús Uriz, Research Professor at the Centro de Estudios Avanzados de Blanes (CEAB), Spain for sponge identification, Pr. Sourisak Sinbandhit and Pr. Philippe Jehan from CRMPO and Pr. Arnaud Bondon from PRISM platform at Rennes University, France for the NMR and MS, and the CNRST of Morocco for the support of the mobility of the researchers of this project.

\section{Author details}

${ }^{1}$ Faculty of Science, University of Chouaib Doukkali, El-Jadida, Morocco. ${ }^{2}$ MMS Research Group, Faculty of Pharmacy, University of Nantes, Nantes, France. ${ }^{3}$ Director of National School of Business and Management (ENCG), El Jadida, Morocco.

Received: 14 January 2013 Accepted: 28 March 2013

Published: 4 June 2013

\section{References}

Ayyad SEN, Bahaffi SOS, Hashish NE (2009) Isolation and structure determination of the biologically active sphingolipids from marine sponge Haliclona species. Nat Prod Res 23(1):44-50. doi:10.1080/14786410701768246

Baker PW, Kennedy J, Dobson AD, Marchesi JR (2009) Phylogenetic diversity and antimicrobial activities of fungi associated with Haliclona simulans isolated from Irish coastal waters. Mar Biotechnol (NY) 11(4):540-547. doi:10.1007/ s10126-008-9169-7

Bibel DJ, Aly R, Shah S, Shinefield HR (1993) Sphingosines: antimicrobial barriers of the skin. Acta Derm Venereol 73(6):407-411

Bibel DJ, Aly R, Shinefield HR (1995) Topical sphingolipids in antisepsis and antifungal therapy. Clin Exp Dermatol 20(5):395-400

Canales M, Hernandez T, Serrano R, Hernandez LB, Duran A, Rios V, Sigrist S, Hernandez HL, Garcia AM, Angeles-Lopez O, Fernandez-Araiza MA, Avila G (2007) Antimicrobial and general toxicity activities of Gymnosperma glutinosum: a comparative study. J Ethnopharmacol 110(2):343-347. doi:10.1016/j.jep.2006.10.002

Clark RJ, Garson MJ, Hooper JN (2001) Antifungal alkyl amino alcohols from the tropical marine sponge Haliclona n. sp. J Nat Prod 64(12):1568-1571

Dube A, Singh N, Saxena A, Lakshmi V (2007) Antileishmanial potential of a marine sponge, Haliclona exigua (Kirkpatrick) against experimental visceral leishmaniasis. Parasitol Res 101(2):317-324. doi:10.1007/s00436-007-0469-z

El-Amraoui B, Biard JF, Uriz MJ, Rifai S, Fassouane A (2010) Antifungal and antibacterial activity of porifera extracts from the moroccan atlantic coasts. J Mycol Med 20(1):70-74. doi:10.1016/j.mycmed.2009.11.001 
Erickson KL, Beutler JA, Cardellina IJ, Boyd MR (1997) Salicylihalamides A and B, novel cytotoxic macrolides from the marine sponge Haliclona sp. J Org Chem 62(23):8188-8192

Faulkner DJ (2002) Marine natural products. Nat Prod Rep 19(1):1-48

Fusetani N, Yasumuro K, Matsunaga S, Hirota H (1989) Haliclamines A and B, cytotoxic macrocyclic alkaloids from a sponge of the genus Haliclona. Tetrahedron Lett 30(49):6891-6894. doi:10.1016/50040-4039(01)93381-7

Galeano E, Martínez A (2007) Antimicrobial activity of marine sponges from urabá gulf, Colombian Caribbean region. J Mycol Med 17(1):21-24. doi:10.1016/j. mycmed.2006.12.002

Meyer BN, Ferrigni NR, Putnam JE, Jacobsen LB, Nichols DE, McLaughlin JL (1982) Brine shrimp: a convenient general bioassay for active plant constituents. Planta Med 45(1):31-34

Padmaja R, Arun PC, Prashanth D, Deepak M, Amit A, Anjana M (2002) Brine shrimp lethality bioassay of selected Indian medicinal plants. Fitoterapia 73(6):508-510

Radhika P, Rao PR, Archana J, Rao NK (2005) Anti-inflammatory activity of a new sphingosine derivative and cembrenoid diterpene (lobohedleolide) isolated from marine soft corals of Sinularia crassa TIXIER-DURIVAULT and Lobophytum species of the Andaman and Nicobar Islands. Biol Pharm Bull 28(7):1311-1313

Rahman A-U, Choudhary MI, Thomsen WJ (2001) Bioassay techniques for drug development. Harwood academic, British library, UK

Rashid MA, Gustafson KR, Boswell JL, Boyd MR (2000) Haligramides A and B, two new cytotoxic hexapeptides from the marine sponge Haliclona nigra. J Nat Prod 63(7):956-959

Regoli F, Nigro M, Chierici E, Cerrano C, Schiapparelli S, Totti C, Bavestrello G (2004) Variations of antioxidant efficiency and presence of endosymbiotic diatoms in the Antarctic porifera Haliclona dancoi. Mar Environ Res 58(2-5):637-640. doi:10.1016/.jmarenvres.2004.03.055

Rifai S, Fassouane A, Kijjoa A, Soest RV (2004) Antimicrobial activity of untenospongin $\mathrm{B}$, a metabolite from the marine sponge Hippospongia communis collected from the Atlantic coast of morocco. Mar Drugs 2:147-153

Rifai S, Fassouane A, Pinho PM, Kijjoa A, Nazareth N, São M, Nascimento J, Herz W (2005) Cytotoxicity and Inhibition of lymphocyte proliferation of Fasciculatin, a linear furanosesterterpene Isolated from Ircinia variabilis collected from the Atlantic Coast of Morocco. Mar Drugs 3:15-21

Topsent E (1888) Contribution à l'étude des Clionides. Archives de Zoologie expérimentale et générale 5 bis(2):1-165, pls I-VII

Volk Christian A, Lippert H, Lichte E, Köck M (2004) Two New haliclamines from the arctic sponge Haliclona viscosa. Eur J Org Chem 2004(14):3154-3158. doi:10.1002/ejoc.200400026

Volk CA, Kock M (2003) Viscosamine: the first naturally occurring trimeric 3-alkyl pyridinium alkaloid. Org Lett 5(20):3567-3569. doi:10.1021/ol035006i

Volk CA, Kock M (2004) Viscosaline: new 3-alkyl pyridinium alkaloid from the Arctic sponge Haliclona viscosa. Org Biomol Chem 2(13):1827-1830 doi:10.1039/b403413a

doi:10.1186/2193-1801-2-252

Cite this article as: El-Amraoui et al.: Haliscosamine: a new antifungal sphingosine derivative from the Moroccan marine sponge Haliclona viscosa. SpringerPlus 2013 2:252.

\section{Submit your manuscript to a SpringerOpen ${ }^{\circ}$ journal and benefit from:}

- Convenient online submission

- Rigorous peer review

- Immediate publication on acceptance

- Open access: articles freely available online

- High visibility within the field

- Retaining the copyright to your article

Submit your next manuscript at $\gg$ springeropen.com 